\title{
Quantified impact of market interest rates on commercial banks' business mix
}

\author{
Eva Kostikov \\ Department of Finance, \\ University of Finance and Administration, \\ Crech Republic \\ evacipovova@gmail.com \\ Petra Jílková \\ Masaryk Institute of Advanced Studies, \\ Czech Technical University in Prague, \\ Czech Republic \\ petra.jilkova@cout.cz.

\section{Pavla Kot'átková Stránská} \\ Masaryk Institute of Advanced Studies, \\ Czech Technical University in Prague, \\ Czech Republic \\ pavla.kotatkova.stranska@cvut.cz.
}

Abstract. The main aim of this paper is to measure the influence of market interest rate on commercial banks' business mix. The global character of banking business and the conditions of the world economy have caused extremely low interest rates at the loan and mortgage market in Czech Republic. Low interest rates generate cheaper money and make loans and mortgages easily available since 2014 where the mortgage interest rate dropped below the level of $2.5 \%$. The first aim of this research is to evaluate the effect from different types of interest rates on two types of loan products in this five-year period (2014-2018). The second aim of this research is to analyse the effect from the selected interest rates in Czech Republic on profitability of the selected commercial banks. Lastly, profitability behaviour of the banking sector in Czech Republic and its relation with the selected interest rates and bank-specific determinants has been examined. Our final results state that the consumption interest rate, mortgage interest rate, deposit interest rate, PRIBOR $2 \mathrm{w}$-repo, inflation rate, disposable income, unemployment, GDP and the real effective exchange rate (REER) have significant influence on the volume of mortgage loans and consumer loans too. The authors find that banks' ROE is affected by profit margin and liquidity, but it is negatively related to financial leverage and the 
number of provided loans. Lastly, the consumer loan volume has a negative influence on the return on equity. The results show the positive relationship between ROE and mortgage loan volume but negative effect of consumer loan volume on the return on equity.

Keywords: interest rates, marketing mix profitability of commercial banks, banking products, multiple linear regression.

JEL Classification: G20, G32, G21, C12, C40

\section{INTRODUCTION}

Global character of the banking business and the conditions of the world economy have caused extremely low interest rates at the loan and mortgage market in Czech Republic. Czech central bank has tightened mortgage rules to prevent banks getting caught up in spiral lending. Low interest rates combined with improving economic prospects and rising incomes have resulted in increasing demand for houses. Although loan and mortgage interest rates are rising slowly, they still remain on a very low level. The zero or negative interest rates of the past years influenced the behaviour of many entities in the economy of financial and non-financial institutions, companies and households. Low interest rates generate cheaper money and make loans and mortgages easily available. On the other hand, they convey a negative message primarily to savers as a very low return on investment. In comparison with other EU countries, Czech population is more conservative and find low interest rates rather problematic. It is, however, expected that low interest rates charged on the savings products cannot prevent inflation.

The aim of this research is twofold. Firstly, the impact of interest rates on the selected loan products has been assessed. Different types of interest rates are considered, i.e., consumer interest rates, mortgage interest rates and interbank market interest rates such as PRIBOR and two-week repo rate. Secondly, this research analyses the effect of the selected interest rates in Czech Republic on profitability of the selected commercial banks and on the banking product policy using the method of multiple linear regression. Finally, this research examines the profitability behaviour of the banking sector related to defined interest rates, and bank-specific determinants, using data of Czech Republic retail bank institutions over the period 2014-2017, quarterly based.

\section{LITERATURE REVIEW}

Relationship lending, the most common techniques for lending to small firms, is based on the "soft" information which is accessible by keeping a close relationship with the client (Rahman et al., 2018; Sobeková Majková, 2016; Ključnikov et al., 2016). Alternatively, there exist transaction-based lending techniques, those are mainly based on the "hard" information about the businesses. For example, financial statements based lending, asset based lending and credit scoring (Petersen \& Rajan, 2002). Researches dealing with the soft information generation and bank lending efficiency argue that the soft information collection and careful examination of the information can increase the lending efficiency of the bank that can positively affect the small business access to credit (D'Aurizio et al., 2015). On the other hand, empirical results show that commercial banks can improve the credit rating model by including the relationship lending qualitative (soft) information of the borrower in the rating process, and that focus only on the hard financial information can be misleading (Dolezal et al., 2015; Cipovová \& Belás, J., 2012). 
Bank profitability over time is according Diewert (2014) defined as the value of production produced by the production unit divided by the corresponding costs. Feng \& Wang, (2018) analyzed the profitability of European banks compared to their US counterparts by dividing the relative profitability into two price indexes. They showed that the decline in the output-input price index was due to a decline in the relative interest rate and relative return on securities and an increase in funding costs, while a decline in the productivity index was due to a decline in technical efficiency, scale efficiency, and residual mix efficiency.

Interest rates have the effect on bank profitability, it could be said that it is a major determinant of the bank capital. A number of presented papers, the impact of macroeconomic factors and changes in the structure of the banking sector on the bank profitability, namely the influence on ROAA or ROAE (return on average assets and return on average equity). Transmission mechanism is a process in which monetary policy decisions are transmitted into changes in real GDP and inflation. There are a lot of different views among authors. Firstly, the transmission of monetary policy is through interest rate mechanisms and there must be mentioned the traditional Keynesian model, which indicates a contractionary monetary policy leading to a rise in real interest rates (i), which in turn raises the cost of capital, thereby causing a decline in investment spending (I), thereby leading to a decline in aggregate demand and a fall in output $(\mathrm{Y})$. The interest rate level of monetary transmission is outlined in the schematic $\downarrow \mathrm{M} \rightarrow \uparrow \mathrm{i} \rightarrow \downarrow \mathrm{I} \rightarrow \downarrow \mathrm{Y} . \quad$ (Mishkin, 1995) Secondly, there is a transmission mechanism of monetary policy through the exchange rate mechanism. Taylor (1995) emphasized that the framework for this issue must be extended to international extended. It means that the changes in exchange rates have been a key part of the monetary transmission mechanism in his theory. The schematic for the monetary transmission mechanism operating through the exchange rate is outlined in the schematic $\downarrow \mathrm{M} \rightarrow \uparrow \mathrm{i} \rightarrow \uparrow \mathrm{E}$ (a rise in the value of deposits relative to other currency) $\rightarrow \downarrow N X$ (a fall in net exports) $\rightarrow \downarrow$ Y. (Mishkin, 1995).

The impact of interest rates to the real banks' business mix has been the topic of theoretical and empirical researches, starting in the early 1980s; there is a growing literature studies concerned with the validity of the credit channel theory. A lot of authors describe the impact of macroeconomic dynamics and changes in the structure of the banking sector on bank profitability and the role of interest rates has received significant attention such as (Romer \& Romer, 1990; Ramey, 1993; Bernanke \& Blinder, 1995; Kashyap \& Stein, 2000; Albertazzi \& Gambacorta, 2009). The banks'business mix is based on traditional service marketing mix framework (7Ps). Schultz et al. (1993) proposed a consumer oriented 4Cs framework and shifting focus to satisfying consumer needs. Ngo \& Pavelková, (2017) found that positive switching costs increase customer loyalty by partly transforming the effect of service value and customer satisfaction into customer loyalty.

Horvath (2009) investigated the determinants of the interest rate margins of Czech banks based on quarterly data in 2000-2006 using the Arrelano-Bond dynamic panel data estimator. The result stated that more efficient banks exhibit lower margins and there is no evidence that banks with lower margins compensate themselves with higher fees. Dumičić and Rizdak (2013) analysed the main net interest margin determinants of banks operating in Central and Eastern European countries from 1999 to 2010. The result of this study examined that there is the positive link between GDP growth and net interest margin, implying that periods of high growth can result in higher net interest margins due to more intense credit activity and better loan quality.

Study about determinants of banks' profitability in EU27 over the period 2004-2011 where Petria, Capraru \& Ihnatov (2015) indicate credit and liquidity risk, management efficiency, the diversification of business, the market concentration/competition and the economic growth have significant influence on bank profitability. An interesting and valuable result is the positive influence of competition on bank 
profitability in EU27, where better supervision for credit and liquidity risk of banks and the encouraging of banking competition has been suggested.

Most of literature estimated the determinants of banking profitability (Gavurova et al., 2017) which is based on the efficient and stable performance of commercial banks using for example the Return on Assets (ROA) or Return on Equity (ROE). Another valuable paper is the Bank of Greece Research and its Determinants of Bank Profitability over the period 1998-2002; Athanasoglou, Delis \& Staikouras (2006) found that banks' profits are not significantly affected by the real GDP per capita as follows:

Table 1

Dependent and independent variable

\begin{tabular}{|c|c|c|c|c|c|}
\hline & Variable & Measure & Notation & $\begin{array}{l}\text { Exp. } \\
\text { effect }\end{array}$ \\
\hline \multirow{2}{*}{\multicolumn{2}{|c|}{ Dependent Variable }} & \multirow[t]{2}{*}{ Profitability } & $\begin{array}{c}\text { Net Profits (before taxes) / } \\
\text { equity }\end{array}$ & \multirow[t]{2}{*}{$\begin{array}{c}\text { ROA or } \\
\text { ROE }\end{array}$} & \\
\hline & & & $\begin{array}{c}\text { Net Profits (before taxes) / } \\
\text { assets }\end{array}$ & & \\
\hline \multirow[t]{11}{*}{ Determinants } & Bank-specific & Liquidity & Loans / assets & LA & Positive \\
\hline & & Credit risk & Loan loss provisions / loans & LLP & Positive \\
\hline & & Capital & Equity/ assets & EA & Negative \\
\hline & & $\begin{array}{c}\text { Operating expenses } \\
\text { management }\end{array}$ & Operating expenses / assets & OEA & Negative \\
\hline & & Size & In real assets & $\mathrm{S}$ & $\mathrm{X}$ \\
\hline & & Foreign ownership & $\begin{array}{l}\text { Binary dummy variable equal } \\
\text { to one for foreign banks }\end{array}$ & Dfo & $\mathrm{X}$ \\
\hline & & Market Share & $\begin{array}{l}\text { Market Share of individual } \\
\text { banks }\end{array}$ & MS & $\mathrm{X}$ \\
\hline & Industry related & $\begin{array}{l}\text { Banking system } \\
\text { reform }\end{array}$ & EBRD & EBRD & $\mathrm{X}$ \\
\hline & & Concentration & Herfindahl-Hirschman index & $\mathrm{HHI}$ & $\mathrm{X}$ \\
\hline & Macroeconomic & Inflation & Current period inflation rate & INF & $\mathrm{X}$ \\
\hline & & Economic activity & Real per capita income & RCG & Positive \\
\hline
\end{tabular}

Source: Athanasoglou, Delis and Staikouras (2006)

Ongore \& Kusa (2013) analyse the factors affecting the ROA, ROE and NIM as dependent variables and "liquidity ratio, asset quality, capital adequacy, management efficiency, GDP and inflation" as independent variables. There was a significant impact of capital adequacy, asset quality and management efficiency on Kenya banks' profitability. Claessens et al., (2018) investigated the relationship between changes in interest rates, NIMs (net interest margin), and profitability for a large sample of banks in a wide spectrum of countries over a long period. Their research identified an adverse effect of low interest rates on banks' NIMs and profitability. As banking systems in many low interest rate countries already had relatively low NIMs, those especially will have to adjust their activities and cost structures so as to offset low rates' adverse effects on profitability and capital.

According to Căpraru \& Ihnatov (2014) which examined bank’s profitability in Romania, Hungary, Poland, Czech Republic and Bulgaria between 2004 and 2011 stated that the capital adequacy effects the bank profitability for all performance proxies while credit risk and inflation determine only return on average assets and return on average equity. They also indicate that banks with higher capital adequacy are more profitable. Borio et al., (2017) investigated how monetary policy affects bank profitability in 14 major advanced economies for the period 1995-2012. Their research identified an adverse effect of low interest rates on banks' NIMs and profitability, it means that there is the correlation between the level of interest rates and the steepness of the yield curve, on the one hand, and ROA, on the other, is positive: 
higher rates and a steeper yield curve boost profitability. Altavilla et all., (2018) confirmed this fact that low monetary rates have a negative effect on profits that, however, only materializes after a long time period and is counterbalanced by improved macroeconomic conditions associated with low interest rates.

Vodová (2014) in her study examined the financial performance of the commercial banks through different levels of liquidity in the Czech Republic between 2001 -2009. She found out that the bank liquidity is positively related to capital adequacy, interest rates on loans, share of non-performing loans and interest rate on interbank transaction and negatively related to inflation rate, business cycle and financial crisis. The results show also that small banks are more liquid than big banks which corresponds with the "too big to fail" hypothesis. If big banks are seeing themselves as "too big too fail", their motivation to hold liquid assets is limited. It was also found out that unemployment, interest margin, bank profitability and monetary policy interest rate have no statistically significant effect on the liquidity of Czech commercial banks which sounds very interesting.

\section{METHODOLOGY}

The study is based on time series, which covers a period from 2014 to January 2018 - monthly data (for model III, data was quarterly per period 2008 - 2017). Data for model I., II. were collected from the Czech National Bank (CNB) and also from the annual reports of the selected banks which are available on their websites. Data for model III. - IV. were collected from the BANKSCOPE database.

From a statistical point of view, the basis for this article is using a formula for the function of the multiple-linear regression. This research follows function according (Mendenhall, 2016, López-Espín, 2012):

$$
Y=\beta_{0}+\beta_{1} X_{1}+\beta_{2} X_{2}+\ldots+\beta_{n} X_{n}+\varepsilon_{i}, \quad \mathrm{i}=1,2, \ldots, \mathrm{n},
$$

where $\mathrm{Y}$ is dependent variable, $\beta \mathrm{i}(\mathrm{i}=1, \ldots, \mathrm{n})$ are the regression coefficients (or partial regression coefficients), $\mathrm{Xi}(\mathrm{i}=1, \ldots, \mathrm{n})$ are independent variables and $\varepsilon_{i}$ is random folder.

MODEL I. allows to examine the effect of the dependent variable Mortgage loan volume (MLV) on independent variables (IR_consuption, IR_mortgage, IR_pribor, IR_deposits, IR_repo2w, inflation, disposable income, unemployment, GDP, REER) according following relation:

$$
\begin{aligned}
& \mathrm{MLV}=\beta_{0}+\beta_{1}\left(\mathrm{IR} \_ \text {consuption }\right)+\beta_{2}\left(\mathrm{IR} \_ \text {mortgage }\right)+\beta_{3}\left(\mathrm{IR} \_ \text {deposits }\right)+\beta_{4}\left(\mathrm{IR} \_ \text {pribor }\right)+ \\
& \beta_{5}\left(\mathrm{IR} \_ \text {repo } 2 \mathrm{w}\right)+\beta_{6}(\text { Inflation })+\beta_{7}(\text { Disposable_income })+\beta_{8}(\text { Unemployment })+\beta_{9}(\mathrm{GDP})+ \\
& \beta_{10}(\mathrm{REER})+\varepsilon
\end{aligned}
$$

MODEL II. allows to examine the effect of the dependent variable Consumer loan volume (CLV) on independent variables (IR_consuption, IR_pribor, IR_deposits, IR_repo2w, inflation, disponable income, unemployment, GDP, REER) according following relation:

$$
\begin{aligned}
& \text { CLV }=\beta_{0}+\beta_{1}\left(\mathrm{IR} \_ \text {consuption }\right)+\beta_{2}\left(\mathrm{IR} \_ \text {mortgage }\right)+\beta_{3}\left(\mathrm{IR} \_ \text {deposits }\right)+\beta_{4}\left(\mathrm{IR} \_ \text {pribor }\right)+ \\
& \beta_{5}\left(\mathrm{IR} \_ \text {repo } 2 \mathrm{w}\right)+\beta_{6}(\text { Inflation })+\beta_{7}(\text { Disposable_income })+\beta_{8}(\text { Unemployment })+\beta_{9}(\mathrm{GDP})+ \\
& \beta_{10}(\mathrm{REER})+\varepsilon
\end{aligned}
$$


MODEL I, II - Dependent and independent variable

\begin{tabular}{|c|c|c|}
\hline Type of Variable & Variable Description & Notation \\
\hline \multirow[t]{2}{*}{ Dependent Variables } & $\begin{array}{l}\text { Mortgage Loan Volume - the volume of mortgage } \\
\text { loans provided by banks }\end{array}$ & (MLV) \\
\hline & $\begin{array}{l}\text { Consumer Loan Volume }- \text { the volume of customer } \\
\text { loans provided by banks included overdrafts, revolving } \\
\text { loans, credit card debt for consumption and households } \\
\text { purchases. }\end{array}$ & $(\mathrm{CLV})$ \\
\hline \multirow[t]{10}{*}{ Independent Variables } & $\begin{array}{l}\text { Consumer Loan Interest Rate - costs for borrowing } \\
\text { included overdrafts, revolving loans, credit card debt for } \\
\text { consumption and household purchases, rates are } \\
\text { calculated as weighted averages. }\end{array}$ & (IR_consumption) \\
\hline & $\begin{array}{l}\text { Mortgage Loan Interest Rate - average rate of interest } \\
\text { charged on a mortgages. }\end{array}$ & (IR_ mortgage) \\
\hline & $\begin{array}{l}\text { PRIBOR (The Prague interbank offered rate) - average } \\
\text { rate on the Czech interbank money market. }\end{array}$ & (IR_pribor) \\
\hline & $\begin{array}{l}\text { Deposit Rate - amount of money paid out in interest by } \\
\text { a bank or financial institution on }\end{array}$ & (IR_deposits) \\
\hline & $\begin{array}{l}\text { Repo Rate - monetary policy } 2 \text {-weeks interest rates - the } \\
\text { maximum limit rate at which banks' bids can be satisfied } \\
\text { in the CNB's } 2 \text { weeks repo tenders. }\end{array}$ & $\left(\mathrm{IR} \_\right.$repo2w) \\
\hline & Inflation - Inflation rate & (inflation) \\
\hline & $\begin{array}{l}\text { Households' Disposable Income - amount of money } \\
\text { that households have available for spending and saving. }\end{array}$ & (Disposable _ income) \\
\hline & Unemployment Rate & (Unemployment) \\
\hline & $\begin{array}{l}\text { Gross Domestic Product per Capita - the share of } \\
\text { public expenditures on gross domestic product }\end{array}$ & (GDP) \\
\hline & $\begin{array}{l}\text { Real Effective Exchange Rate - weighted average of } \\
\text { a country's currency in relation to an index or } \\
\text { basket of other major currencies, adjusted for the } \\
\text { effects of inflation. }\end{array}$ & (REER) \\
\hline
\end{tabular}

Source: Designed by authors based on Literature Review

MODEL III. allows to examine the effect of the dependent variable (indicator ROE) on independent variables (ROA, Total assets, Financial leverage, ROS, Capital adequacy, Liquidity I, Liquidity II, Liquidity III, Liquidity IV, Credit risk, Loans and advances) according following relation:

$$
\begin{aligned}
& \mathrm{ROE}=\beta 0+\beta 1(\mathrm{ROA})+\beta 2(\text { Total_assests })+\beta 3(\text { Financial_leverage })+\beta 4(\mathrm{ROS})+ \\
& \left.\beta 5(\text { Capital_adequacy })+\beta 6\left(\mathrm{~L} \_\mathrm{I}\right)+\beta 7\left(\mathrm{~L} \_\mathrm{II}\right)+\beta 8\left(\mathrm{~L} \_\mathrm{III}\right)+\beta 9(\mathrm{~L}) \mathrm{IV}\right)+\beta 10(\text { Credit_risk })+ \\
& \beta 11(\mathrm{NPL})+\varepsilon
\end{aligned}
$$

MODEL IV. allows to examine the effect of the dependent variable (indicator ROE) on independent variables (MLV) and (CLV) according following relation:

$$
\text { d_ROE }=\beta 0+\beta 1(\mathrm{MLV})+\beta 2(\mathrm{CLV})+\varepsilon
$$


MODEL III, IV - Dependent and independent variable

\begin{tabular}{|c|c|c|}
\hline Type of Variable & Variable Description & Notation \\
\hline Dependent Variables & $\begin{array}{l}\text { ROE }- \text { Return on equity }=\text { ratio of net profit on banks } \\
\text { 'own capital }\end{array}$ & (ROE, d_ROE) \\
\hline \multirow[t]{11}{*}{ Independent Variables } & $\begin{array}{l}\text { ROA }- \text { Return on assets }=\text { ratio of EBIT on total assets } \\
\text { of the bank }\end{array}$ & $(\mathrm{ROA})$ \\
\hline & Total Bank Assets & (Total_asset) \\
\hline & $\begin{array}{l}\text { Financial Leverage - ratio of own capital on total assets } \\
\text { of the bank }\end{array}$ & (Financial_leverage) \\
\hline & $\begin{array}{l}\text { ROS - The ratio of net profit (which is interest income } \\
\text { interest expenses) to total sales of the bank }\end{array}$ & (ROS) \\
\hline & & (Capital_adequacy) \\
\hline & Liquidity I - liquid assets/total assets & $\left(\mathrm{L} \_\mathrm{I}\right)$ \\
\hline & $\begin{array}{l}\text { Liquidity II - liquid assets/(deposits +short term } \\
\text { borrowing) }\end{array}$ & (L_II) \\
\hline & Liquidity III - loans/total assets & (L_III) \\
\hline & Liquidity IV - loans/(deposits + short term borrowing) & (L_IV) \\
\hline & Impaired Loans (NPLs)/Gross Loans & (Credit_risk) \\
\hline & NPL - Number of provided loans & (NPL) \\
\hline
\end{tabular}

Source: Designed by authors based on Literature Review

Before assembling the model, it is necessary to input values to test for stationarity assumption. Stationarity assumption is verified by the ADF test. (López-Espín, 2012; Greene, 2003). The resulting model of linear regression is need to test for heteroscedasticity according to Breusch-Pagan test. It tests whether the variance of the errors from a regression is dependent on the values of the independent variables. The basis of the Breusch-Pagan test is a chi-squared test. If the test statistic has a p-value below an appropriate threshold (e.g. $\mathrm{p}<0.05$ ) then the null hypothesis of homoscedasticity is rejected and heteroskedasticity assumed. (Greene, 2003; López-Espín, 2012)

\section{EMPIRICAL RESULTS AND DISCUSSION}

Interest rates are fundamentally influenced by the base rate announced by the Czech National Bank (CNB). It is usually uses three base rates (Lombard rate, Deposit rate and Repo rate used for repo operations). Thanks to the interest rate transmission mechanism, the central bank's base rates are first projected into short-term rates on the inter-bank market and then on long-term rates that already affect the behavior of all financial market participants, including households. We could expect that the rising Mortgage and Consumer loan volume can be the metric for positive banks' business mix. The Interest Rate Structure in the Czech Republic is illustrated also in Fig. 1 below, which shows the development of the REPO rate announced by the $\mathrm{CNB}, 14$-day interbank rates and annual banks' interest rates.

Validation of the assumption of non-stationarity eliminates the appearance of a seeming regression. The existence of apparent regression causes the statistically significant estimates of the regression function parameters to be unconnected. The data was tested ADF test at significance level of 0.05 . The condition of "stationarity" was confirmed. The data was also verified for the assumption of multicollinearity. The pair correlation coefficient is less than 0.8. The models of linear regression (MODEL I. and MODEL II.) verified in terms of residual analysis, determination index, and statistical significance of regression parameters. It used Breusch-Pagan test for testing normality of residual. The null hypothesis was not 
rejected. The residues fulfil the condition of homoscedasticity (p-values were $0.1112-0.2135$ ). Processing took place using SW GRETL.

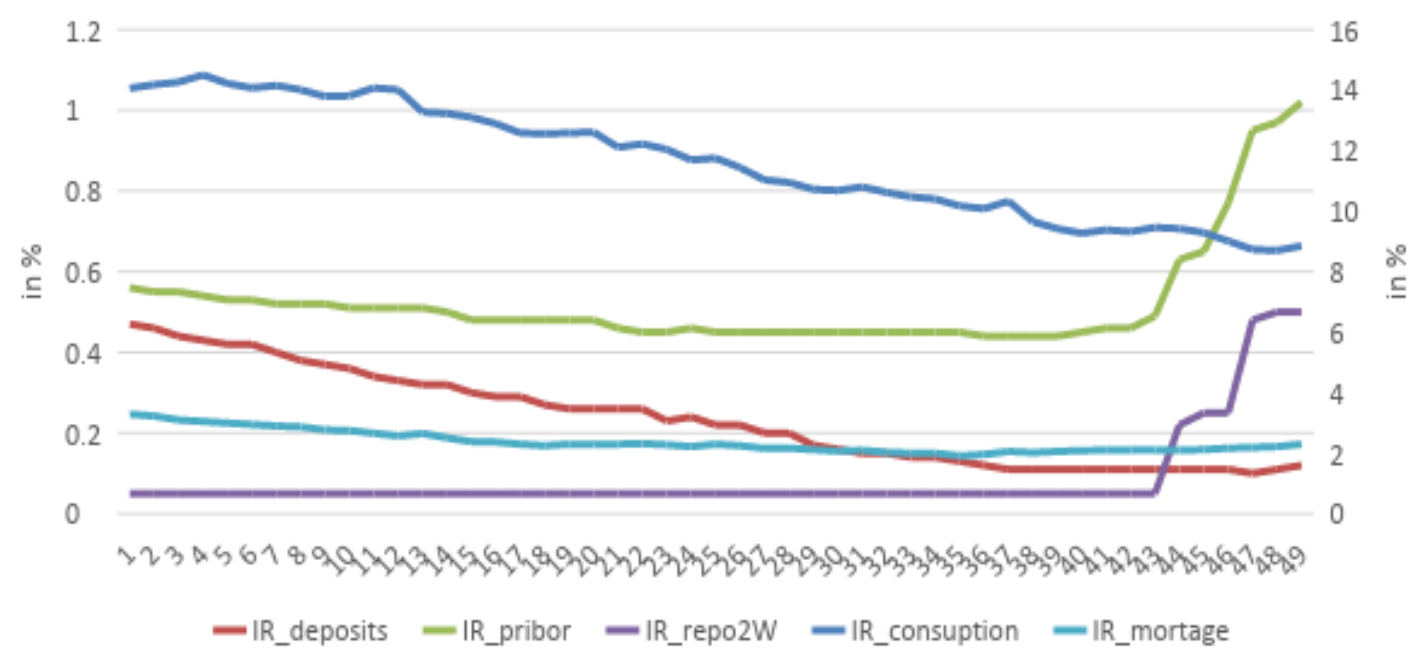

Figure 1. Interest Rate Structure (2014-2018 monthly based)

Source: Own sources based on (CNB, 2018)

The result will also be the quantification of the relationship with subsequent verification provided for the null hypothesis of statistical significance through appropriately selected statistical test. This step is included in the regression diagnostics, which we will evaluate the multiple-linear regression model, fully assembled.

From the above, it is therefore fixed the null hypothesis H0: the selected indicator is not statistically significant on the chosen level of significance, as well as the null hypothesis H0: assembled model is statistically insignificant.

Table 4

Result of MODEL I. - Dependent variable: MLV

\begin{tabular}{|l|c|c|}
\hline & Coefficient $\boldsymbol{\beta}$ & p-value \\
\hline IR_consuption & -1728.80 & $0.02796^{*}$ \\
\hline IR_deposits & 35310.5 & $0.0201 *^{*}$ \\
\hline IR_pribor & 15294.2 & $0.03577^{*}$ \\
\hline IR_mortage & -20721.6 & $0.00055^{*}$ \\
\hline Disponable_income & -0.2389 & $0.0188 *$ \\
\hline
\end{tabular}

\begin{tabular}{|l|l|}
\hline Coefficient of determination & 0.6793 \\
\hline Modifi.coefficient of determination & 0.6420 \\
\hline P-value (Anova - model) & 0.0000 \\
\hline Durbin_Watson & 1.8081 \\
\hline
\end{tabular}

Source: calculated by authors

Dependent variable "Mortage_loan volume" is positively influenced IR_deposits, IR_pribor, on the contrary dependent variable is negatively influenced IR_consuption, IR_mortage and Disponable_income. 
Result of MODEL II. - Dependent variable: CLV

\begin{tabular}{|l|c|c|}
\hline & Coefficient $\beta$ & p-value \\
\hline IR_deposits & -605840 & 0.0000 \\
\hline IR_pribor & 194923 & 0.0295 \\
\hline IR_repo2W & -158916 & 0.0499 \\
\hline IR_mortage & 94572.3 & 0.0000 \\
\hline Unemployment & -57027.2 & 0.0219 \\
\hline Disponable_income & -0.6433 & 0.0401 \\
\hline
\end{tabular}

\begin{tabular}{|l|c|}
\hline Coefficient of determination & 0.9924 \\
\hline $\begin{array}{l}\text { Modifi.coefficient of } \\
\text { determination }\end{array}$ & 0.9914 \\
\hline P-value (Anova - model) & 0.0000 \\
\hline Durbin_Watson & 1.2646 \\
\hline
\end{tabular}

Source: calculated Source: Athanasoglou Dependent variable "Consuption_loan" is positively influenced IR_pribor, IR_mortage, on the contrary dependent variable is negatively influenced IR_deposits, IR_repo2w, Unemployment and Disponable_income.

Table 6

Result of MODEL III. - ROE

\begin{tabular}{|l|c|c|}
\hline & Coefficient $\beta$ & p-value \\
\hline ROA & 5.6587 & $0.0005^{*}$ \\
\hline Financial_leverage & -433.431 & $0.0000^{*}$ \\
\hline ROS & 60.3760 & $0.0000^{*}$ \\
\hline L_III & 39.1488 & $0.0000^{*}$ \\
\hline NPL & -0.00001 & $0.0000^{*}$ \\
\hline
\end{tabular}

\begin{tabular}{|l|c|}
\hline Coefficient of determination & 0.9585 \\
\hline $\begin{array}{l}\text { Modifi.coefficient of } \\
\text { determination }\end{array}$ & 0.9427 \\
\hline P-value (Anova - model) & 0.0000 \\
\hline Durbin_Watson & 1.7723 \\
\hline
\end{tabular}

Source: calculated by authors

Dependent variable "ROE" is positively influenced by ROA, ROS and Liquidity III, on the contrary dependent variable is negatively influenced by Financial leverage and the number of provided loans (included loans and advances).

Table 7

Result of MODEL III. - d_ROE

\begin{tabular}{|l|c|c|}
\hline & Coefficient $\beta$ & p-value \\
\hline Mortgage_loan_volume & 0.000903 & $0.0076^{*}$ \\
\hline Consumer_loan_volume & -0.000028 & $0.0143^{*}$ \\
\hline
\end{tabular}

\begin{tabular}{|l|c|}
\hline Coefficient of determination & 0.4667 \\
\hline $\begin{array}{l}\text { Modifi.coefficient of } \\
\text { determination }\end{array}$ & 0.3778 \\
\hline P-value (Anova - model) & 0.02317 \\
\hline Durbin_Watson & 2.2757 \\
\hline
\end{tabular}

Source: calculated by authors 
Dependent variable "d_ROE" is positively influenced Mortgage loan volume; on the contrary dependent variable is negatively influenced Consumer loan volume. Initial models included independent variables were identified as insignificant statistic. The variables were eliminated from the models. The Table 4-7 contains only variables that were the model for statistics significant.

\section{CONCLUSION}

The main aim of this paper is to measure the influence of market interest rate on commercial banks' business mix. After examining of the effect of market interest rates on commercial bank's business mix on Czech commercial banks we can conclude that the empirical finding is mainly consisted with the expected results. The impact of the level of interest rates on the bank profitability. By means of a large panel data set consisting of interest rate variables, macroeconomic indicators and bank specific profitability variables, these relationships were measured for the Czech banking sector. First aim of this research was to evaluate the effect of different type of interest rates on two types of loan products in this five-year period (2014 2018). Dependent variable "Mortage_loan volume" is positively influenced by IR_deposits, IR_pribor, on the contrary dependent variable is negatively influenced IR_consuption, IR_mortage and Disponable_income. Dependent variable "Consuption_loan" is positively influenced IR_pribor, IR_mortage, on the contrary dependent variable is negatively influenced IR_deposits, IR_repo2w, Unemployment and Disponable_income. These findings for the Czech Republic is in correspondence to the related literature.

Thus, consumption interest rate, mortgage interest rate, deposit interest rate, PIRBOR two-week repo, inflation rate disposable income, unemployment, GDP and REER have significant influence on the volume of mortgage loans (VML) and consumer loans (VCL) also. Profitability of equity (ROE) is affected by the profit margin and liquidity, but it is negatively related with financial leverage (it means that Czech banks are not using foreign capital for their financing, they stick with own capital which is related with the expensiveness) and the number of provided loans. The assumption of the low interest rate environment deteriorating the bank profitability is confirmed as well. We can state that the lower interest rates are associated with the lower interest margins and based on it with the lower bank profit. The study specifically investigates the effect of various interest rates on bank net interest margins, using aggregate date for the Czech Republic. Last model showed the positive relationship between ROE and mortgage loan volume but negative effect of consumer loan volume on return on equity. While this paper identifies an adverse effect, the analysis does not provide an overall assessment of how low interest rates may affect Czech banking system. There are good reasons to believe that the level of interest rates are associated with higher net interest income. The negative aftermaths of low interest rates on bank profitability are additionally important to consider based on data of the Czech Republic, and has been a subject of international research (see Borio, Gambacorta \& Hofmann, 2017; Claessens, Coleman \& Donnelly, 2018). Because of the higher requirements on capital adequacy since 2013 from Basel III, as a future direction of the research, we intend to deepen the analysis of liquidity of commercial banks and set if the hypothesis "too big too fail" is applicable for Czech commercial bank environment and splitting the sample into the small and medium sized banks and large banks. 


\section{REFERENCES}

Altavilla, C., Boucinha, M., \& Peydró, J. L. (2018). Monetary policy and bank profitability in a low interest rate environment. Economic Policy, 33(96), 531-586. doi: 10.1093/epolic/eiy013

Athanasoglou, P., Delis, M. \& Staikouras, Ch. (2006). Determinants of bank profitability in the South Eastern European region.

Bernanke, B. \& Gertler, M. (1995). Inside the Black Box: The Credit Channel of Monetary Policy Transmission. The Journal of Economic Perspectives, 9(4), 27-48. doi: 10.1257/jep.9.4.27

Balcerzak, A. P., Kliestik, T., Streimikiene, D., \& Smrčka, L. (2017). Non-parametric approach to measuring the efficiency of banking sectors in European Union Countries. Acta Polytechnica Hungarica, 14(7), 51-70. doi: 10.12700/APH.14.7.2017.7.4

Borio, C., Gambacorta, L., \& Hofmann, B. (2017). The influence of monetary policy on bank profitability. International Finance, 20(1), 48-63. doi: 10.1111/infi.12104

Căpraru, B., \& Ihnatov, I. (2014). Banks’ Profitability in Selected Central and Eastern European Countries. Procedia Economics and Finance, 16, 587-591. doi: 10.1016/S2212-5671(14)00844-2.

Cipovová, E., \& Belás, J. (2012). Assessment of Credit Risk Approaches in Relation with Competitiveness Increase of the Banking Sector. Journal of Competitiveness, 4(2), 69-84. doi: 10.7441/joc.2012.02.05

Claessens, S., Coleman, N., \& Donnelly, M. (2018). "Low-For-Long” interest rates and banks' interest margins and profitability: Cross-country evidence. Journal of Financial Intermediation, 35, 1-16. doi: 10.17016/IFDP.2017.1197

CNB. (2018). ARAD. [online] [2018-04-05]. Retrieved from http://www.cnb.cz/cnb/STAT.ARADY

Diewert, W. E. (2014). Decompositions of profitability change using cost functions. Journal of Econometrics, 183(1), 5866. doi: 10.1016/j.jeconom.2014.06.009

Doležal, J., Šnajdr, J., Belás, J., \& Vincúrová, Z. (2015). Model of the loan process in the context of unrealized income and loss prevention. Journal of International Studies, 8(1), 91-106.

Dumičić, M., \& Rizdak, T. (2013). Determinants of banks' net interest margins in Central and Eastern Europe. Financial theory and practice, 37(1), 1-30.

Feng, G., \& Wang, C. (2018). Why European banks are less profitable than US banks: A decomposition approach. Journal of Banking \& Finance, 90, 1-16. doi: 10.1016/j.jbankfin.2018.02.017

Gavurova, B., Belas, J., Kocisova, K., \& Kliestik, T. (2017). Comparison of Selected Methods for Performance Evaluation of Czech and Slovak Commercial Banks. Journal of Business Economics and Management, 18(5), 852876. doi: 10.3846/16111699.2017.1371637.

Greene, W. (2003) Econometric analysis. New Yersey: Pearson Education. ISBN 978-0-273-75356-8

Gul, S., Irshad, F., \& Zaman, K. (2011). Factors Affecting Bank Profitability in Pakistan. Romanian Economic Journal, 14(39).

Horvath, R. 2009. The determinants of the interest rate margins of Czech banks. Journal of Economics and Finance, 59(2), 128-136.

Kashyap, A., \& Stein, J. (2000). What Do a Million Observations on Banks Say about the Transmission of Monetary Policy. American Economic Review, 90(3), 407-428. doi: 10.1257/aer.90.3.407.

Ključnikov, A., Belás, J., Kozubíková, L., \& Paseková, P. (2016). The Entreprenurial Perception of SME Business Environment Quality in the Czech Republic. Journal of Competitiveness, 8(1), 66-78. doi: 10.7441/joc.2016.01.05

López-Espín, J.J., Vidal A.M., \& Giménez, D. (2012). Two-stage least squares and indirect least squares algorithms for simultaneous equations models. Journal of Computational and Applied Mathematics, 15(1), 3676-3684, doi: 10.1016/j.cam.2011.07.005

Mendenhall, W.M, \& Sincich, T.L. (2016). Statistics for Engineering and Sciences. 8th ed. Taylor \& Francis Inc. ISBN 978-14-987-73-1. 
Mishkin, F. (1995). Symposium on the monetary transmission mechanism. Journal of Economic perspectives, 9(4), 3-10. doi: $10.1257 /$ jep.9.4.3

Ngo, V. M., \& Pavelková, D. (2017). Moderating and mediating effects of switching costs on the relationship between service value, customer satisfaction and customer loyalty: investigation of retail banking in Vietnam. Journal of International Studies, 10(1), 9-33. doi:10.14254/2071-8330.2017/10-1/1

Ongore, V. O., \& Kusa, G. B. (2013). Determinants of financial performance of commercial banks in Kenya. International Journal of Economics and Financial Issues, 3(1), 237-252.

Petria, N., Capraru, B., \& Ihnatov, I. (2015). Determinants of banks' profitability: Evidence from EU 27 banking systems. Procedia Economics and Finance, 20, 518-524. doi: 10.1016/S2212-5671(15)00104-5.

Rahman, A., Rozsa, Z., \& Cepel, M. (2018). Trade Credit and Bank Finance - Evidence from the Visegrad Group. Journal of Competitiveness, 10(3), 132-148. doi.org/10.7441/joc.2018.03.09

Ramey, V. (1993). How important is the credit channel of monetary transmission. Carnegie Rochester Conference Series on Public Policy, 39(0), 1-45.

Romer C., \& D. Romer (1990). New Evidence on the Monetary Transmission Mechanism. Brookings Papers on Economic Activity, 1, 149-213.

Sobeková Majková, M. (2016). The Relationship between the risk of a change of the interest rate and the age of entrepreneurs among Slovak SMEs. Journal of Competitiveness, 8(3), 125-138. doi: 10.7441/joc.2016.03.08

Taylor, J. B. (1995). The monetary transmission mechanism: an empirical framework. Journal of Economic Perspectives, 9(4), 11-26.

Vodova, P. (2013). Liquidity of Czech commercial banks and its determinants. International Journal of Mathematical Models and Methods in Applied Sciences, 5(6), 1060-1067. 